\title{
Follicular lymphoma: too many reminders for a memory B cell
}

\author{
Srividya Swaminathan ${ }^{1}$ and Markus Müschen ${ }^{1,2}$ \\ 'Department of Laboratory Medicine, University of California, San Francisco, San Francisco, California, USA. ²Department of Haematology, University of Cambridge, Cambridge, United Kingdom.
}

\begin{abstract}
Memory B cells are a dynamic subset of the mature B cell population that in some cases can reenter germinal centers (CCs) in response to iterative infections. Such a reactivation can lead to accumulation of genetic lesions in these cells, potentially from repetitive activation of the B cell mutator enzyme AID. Normal memory B cells do not survive repeated reentries into GCs. In this issue, Sungalee et al. demonstrate that memory B cells harboring the oncogenic $B C L 2$ :ICH translocation, which results in constitutive BCL2 expression, survive multiple $\mathrm{CC}$ entries upon repetitive immunization. Through these multiple GC reentries, the hallmark BCL2:ICH translocation enables AID-induced hypermutation and propagates clonal evolution toward malignant follicular lymphoma.
\end{abstract}

B cells decades later (2). The long latency period observed in FL development indicates a prolonged process of clonal evolution. Such a protracted clonal evolutionary process was previously demonstrated in a subset of pre-B cell acute lymphoblastic leukemia (ALL) patients who harbor the ets variant 6 runt-related transcription factor 1 (ETV6-RUNX1) translocation (19-21). Although the ETV6-RUNX1 rearrangement arises in utero (20), less than $1 \%$ of children who carry this rearrangement develop full-blown leukemia, which requires postnatal acquisition of secondary lesions in the preleukemic clone (21).

Only recently have studies begun to elucidate the mechanisms responsible for the long latency period in FL evolution. Multiple studies have shown that $\mathrm{IgM}^{+}$memory B cells get reactivated and can reenter the GC upon antigenic recall (22-24). Importantly, GC reentry is restricted to the $\mathrm{IgM}^{+}$memory B cell subset and does not occur in $\operatorname{IgG}^{+}$memory B cells $(22,23)$. In this issue, Sungalee and colleagues reveal that the iterative GC reentry of $t(14 ; 18)$ (q32; q21)-carrying IgM $^{+}$memory B cells upon chronic immunization is the central driver of follicular lymphomagenesis (25).

\section{Chronic infection drives accumulation of $\mathrm{t}(14 ; 18)$ (q32;q21) B cells}

Sungalee and colleagues developed murine models that recapitulate the genesis of FL by elegantly mimicking the sporadic occurrence of the $\mathrm{t}(14 ; 18)(\mathrm{q} 32 ; \mathrm{q} 21)$ translocation in humans (25). BCL2 $2^{\text {tracer }}$ mice harbor an engineered human $B C L 2$ transgene that must undergo rearrangement to be transcribed and is highly expressed in B cells upon activation of the RAG recombinases (25). The same BCL2 transgene could also be transduced via retrovirus into BM precursors, which could then be transplanted into irradiated mice. In humans, the $\mathrm{t}(14 ; 18)(\mathrm{q} 32 ; \mathrm{q} 21)$ breakpoint combines features of RAG-mediated V(D)J recombination and AID-dependent CpG targeting 

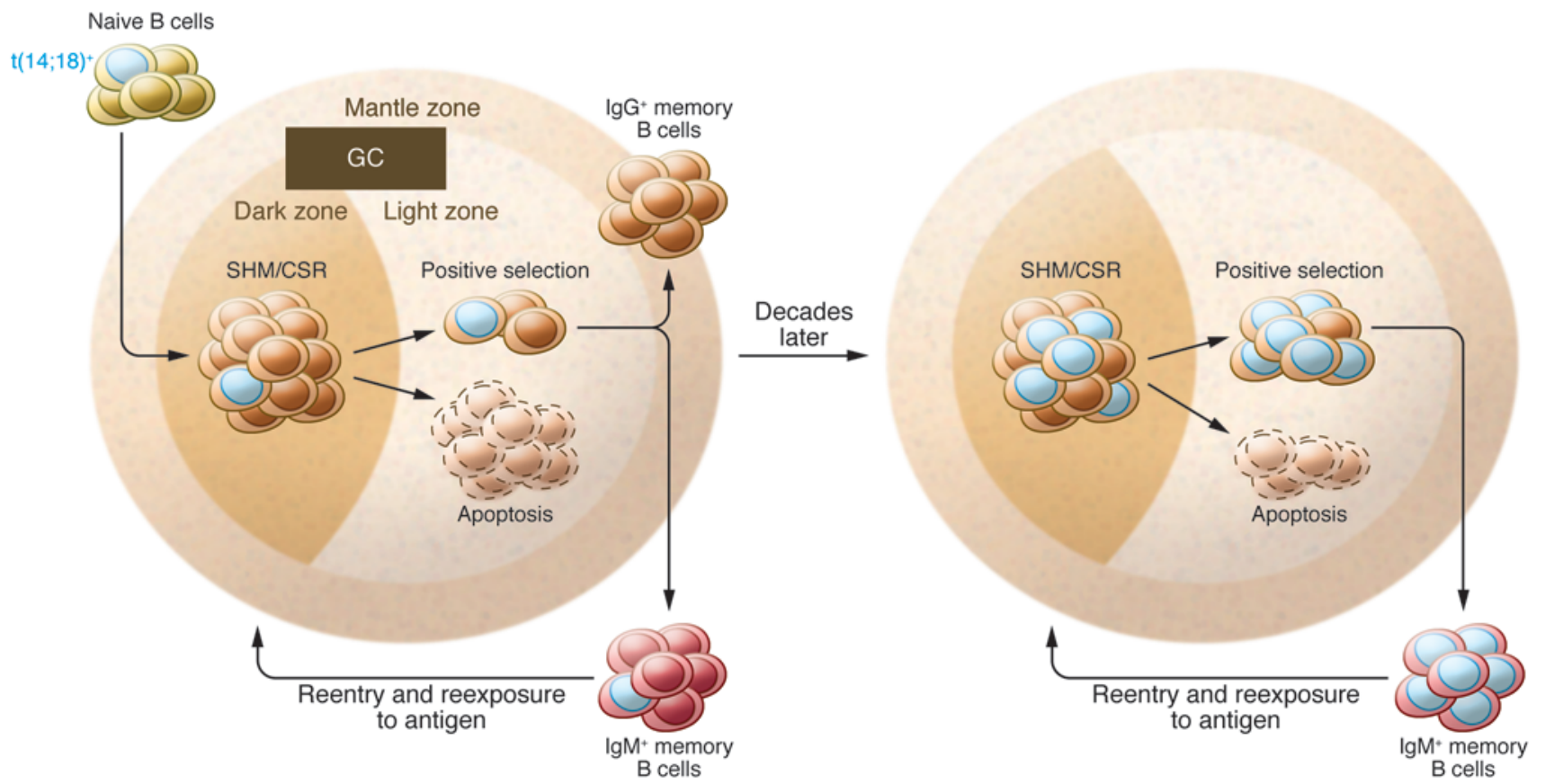

Figure 1. Memory B cell dynamics in the multistep development of follicular lymphoma. (A) Normal and $t(14 ; 18)^{+}$naive $B$ cells both enter into $G C$ reactions upon immunization. GC B cells undergo SHM and CSR. Owing to constitutive BCL2 expression, $t(14 ; 18)^{+}$cells have a survival advantage over normal GC B cells; therefore, $\mathrm{BCL2}$-overexpressing $\mathrm{t}(14 ; 18)^{+}$cells are positively selected into the IgM+ $\mathrm{M}^{+}$memory $\mathrm{B}$ cell pool and are capable of $\mathrm{GC}$ reentry upon reexposure to antigen. With every successive cycle of GC reentry, $t(14 ; 18)^{+}$cells outgrow their healthy counterparts. (B) Decades of iterative GC reentries cause an accumulation of abnormal $\mathrm{t}(14 ; 18)^{+}$cells in the GC (termed FLIS). This process produces a continuous output of $\mathrm{t}(14 ; 18)^{+}$Ig $\mathrm{M}^{+}$memory $\mathrm{B}$ cells, ultimately leading to overt $\mathrm{FL}$.

and typically occurs in pro-/pre-B cells (26). This feature of the $t(14 ; 18)(q 32 ; q 21)$ translocation makes the RAG-dependent $B C L 2^{\text {tracer }}$ model developed by Sungalee et al. physiologically relevant to human disease. Moreover, these models could be tweaked to study perturbations in the frequency of BCL2-expressing B cells in different lymphoid organs. The authors also investigated immunization-induced bidirectional transitions between GC and memory B cells in response to high expression levels of BCL2 (25).

Sungalee and colleagues determined that BCL2-expressing memory B cells are able to reenter the GC following repeated antigen challenges. As demonstrated by the $B C L 2^{\text {tracer }}$ mouse model, a small number of initial GC transits is insufficient for the accumulation of abnormal BCL2expressing B cells and the induction of FL (25). Therefore, the authors proposed and validated that chronic or repetitive antigen exposure is required to induce multiple iterative GC entries and genetic instability. Only BCL2-expressing memory B cells underwent repetitive GC transits by evading apoptosis (ref. 25 and Figure 1).
The authors found that these cells also failed to differentiate after GC passage and continued to express IgM on the surface, thereby continuously accumulating in the IgM $\mathrm{M}^{+}$memory B cell pool (ref. 25 and Figure 1). The impaired differentiation, longer half-life (11), and IgM expression allowed BCL $2^{\text {hi }}$ memory B cells to iteratively reenter the GC at multiple cycles of antigenic recall. Moreover, these features also conferred a survival advantage for these BCL2-expressing B cells compared with normal B cells in the lymphoid follicle (ref. 25 and Figure 1).

Healthy B cells were repeatedly weeded out by subsequent returns to the GC, leaving the developmentally blocked BCL $2^{\text {hi }}$ B cells to colonize the GC and cause FL in situ (FLIS) (Figure 1). Some of these $\mathrm{BCL} 2^{\text {hi }} \mathrm{B}$ cells also disseminated into peripheral lymphoid tissues and were termed FL-like cells (FLLCs). Concordantly, Sungalee and colleagues observed wide dissemination of atypical $\mathrm{t}(14 ; 18)$ (q32; 21$)^{+} \mathrm{B}$ cells in lymphoid tissues from healthy individuals who had no obvious symptoms of FL (25). FLIS and FLLCs both resembled GC B cells and have a $\mathrm{BCL} 2^{+}$
$\mathrm{BCL}^{+/ / \mathrm{lo}}$ phenotype (25). These benign precursors eventually evolve over several decades (up to 20 years) to give rise to fullblown FL $(13,27)$.

Repeated GC transits carry the risk of genetic instability through repetitive exposure to AID expression (28); therefore, lymphomas arising from the GC, such as FLs, display a high degree of DNA damage resulting from SHM and CSR (14, 29-31). The findings by Sungalee et al. (25) build on these observations. Using wholeexome sequencing, the authors found evidence of increased mutations, possibly resulting from AID activity, in both GCs and memory B cells overexpressing BCL2 as compared with empty vectortransduced controls. Moreover, Sungalee and colleagues interrogated their clonal evolution model in humans by comparing the intraclonal variation (ICV) in $\mathrm{t}(14 ; 18)$ (q32; 21$)^{+}$memory B cell clones with that in normal memory B cell clones. In agreement with their earlier findings, ICV was higher in the $\mathrm{t}(14 ; 18)(\mathrm{q} 32 ; \mathrm{q} 21)^{+}$memory B cell clones with an increased rate of SHM and CSR as compared with that in normal counterparts in the same individual (25). 
Thus, the $\mathrm{t}(14 ; 18)(\mathrm{q} 32 ; \mathrm{q} 21)$ translocation supports multiple iterative reentries of $\mathrm{IgM}^{+}$memory B cells into the GC compartment upon chronic immunization and thereby promotes AID-induced hypermutation. Cooperation between these two processes facilitates the malignant transformation of $\mathrm{t}(14 ; 18)(\mathrm{q} 32 ; \mathrm{q} 21)^{+} \mathrm{B}$ cells into overt FL (Figure 1).

\section{Conclusions and future perspectives}

A number of recent studies have shown that chronic and repetitive immune responses trigger reactivation and reentry of $\operatorname{IgM}^{+}$memory B cells into the GC (22-24). This was unexpected, because earlier studies using genetic removal of a cognate antigen demonstrated that long-lived memory B cells do not need "reminders," such as antigen persistence and reentry into GCs. Memory B cells that have evolved high-affinity antibodies are highly valuable to the adaptive immune system and therefore were thought to be exempt from GC reentry and the risk of permanent deletion from the repertoire (32). A possible explanation for this paradox lies in the coevolution of antibodies and antigens. For example, viral, parasitic, and bacterial antigens often self-mutate to evade host immune defenses (33-36). Such antigenic coevolution necessitates multiple reentries of memory B cells into GCs to "update" the repertoire and raise robust and high-affinity antibodies against genetically evolving pathogens. Sungalee et al. elegantly demonstrate that this normal physiological process can be subverted by $\mathrm{t}(14 ; 18)(\mathrm{q} 32 ; \mathrm{q} 21)$ translocation and ultimately cause FL (25).

The "chronic infection model," which links memory B cell dynamics and follicular lymphomagenesis, has several important implications. First, it provides an excellent example of the initiation of lymphoid malignancies from defects in normal physiological processes, which is exemplified by the memory B cell dynamics demonstrated by Sungalee et al. Second, it dispels the theory that constitutive BCL2 expression is sufficient to allow FL progression. Third, the model supports the increased incidence of disease with age. Fourth, the presence of AID activity in $\mathrm{t}(14 ; 18)(\mathrm{q} 32 ; \mathrm{q} 21)^{+}$cells explains FL evolution at a molecular level. Finally, the observations by Sungalee et al. provide proof of principle for previous epidemiological studies suggesting that delayed, recurrent, and chronic infections predispose humans to developing B lymphoid malignancies (37-41).

In light of the findings of Sungalee and colleagues (25), it may be worthwhile to investigate whether these studies can be extended to further examine other $\mathrm{B}$ lymphoid malignancies that require additional genetic lesions for transformation. Studies in this direction may unveil a previously unidentified mechanism by which infection leads to clonal evolution in certain subgroups of pediatric pre-B cell leukemias. Such investigations are ongoing for the ETV6-RUNX1 subgroup of pre-B cell ALL, in which Greaves and Wiemels have proposed that delayed pathogen exposure resulting in chronic and damaging immune responses during early childhood may predispose children carrying this rearrangement to overt leukemia (the so-called "delayed infections hypothesis," refs. 37,38 ).

\section{Acknowledgments}

This work is supported by grants from the National Cancer Institute (NCI), NIH （R01CA137060， R01CA139032, R01CA157644, R01CA169458, and R01CA172558, to M. Müschen); Translational Research Program grants from the Leukemia and Lymphoma Society (6132-09, 6097-10, and 6221-12); the William Lawrence and Blanche Hughes Foundation; and the California Institute for Regenerative Medicine (CIRM) (TR201816, to M. Müschen). M. Müschen is a Scholar of the Leukemia and Lymphoma Society and a Senior Investigator of the Wellcome Trust.

Address correspondence to: Markus Müschen, Department of Laboratory Medicine, Box 0134, University of California, San Francisco, San Francisco, California 94143-0134, USA. Phone: 415.502.0388; E-mail: markus.muschen@ucsf.edu.

1. Glass AG, Karnell LH, Menck HR. The National Cancer Data Base report on non-Hodgkin's lymphoma. Cancer. 1997;80(12):2311-2320.

2. Roulland S, Lebailly P, Lecluse Y, Heutte N, Nadel $\mathrm{B}$, Gauduchon P. Long-term clonal persistence and evolution of $\mathrm{t}(14 ; 18)$-bearing $\mathrm{B}$ cells in healthy individuals. Leukemia. 2006;20(1):158-162.
3. Weiss LM, Warnke RA, Sklar J, Cleary ML. Molecular analysis of the $t(14 ; 18)$ chromosomal translocation in malignant lymphomas. $\mathrm{N} \mathrm{EnglJ}$ Med.1987;317(19):1185-1189.

4. Horsman DE, Gascoyne RD, Coupland RW, Coldman AJ, Adomat SA. Comparison of cytogenetic analysis, southern analysis, and polymerase chain reaction for the detection of $\mathrm{t}(14$; 18) in follicular lymphoma. Am J Clin Pathol. 1995;103(4):472-478.

5. Graninger WB, Seto M, Boutain B, Goldman P, Korsmeyer SJ. Expression of Bcl-2 and Bcl-2-Ig fusion transcripts in normal and neoplastic cells. JClin Invest. 1987;80(5):1512-1515.

6. Hockenbery D, Nuñez G, Milliman C, Schreiber $\mathrm{RD}$, Korsmeyer SJ. Bcl-2 is an inner mitochondrial membrane protein that blocks programmed cell death. Nature. 1990;348(6299):334-336.

7. McDonnell TJ, et al. bcl-2-immunoglobulin transgenic mice demonstrate extended B cell survival and follicular lymphoproliferation. Cell. 1989;57(1):79-88.

8. Egle A, Harris AW, Bath ML, O’Reilly L, Cory S. VavP-Bcl2 transgenic mice develop follicular lymphoma preceded by germinal center hyperplasia. Blood. 2004;103(6):2276-2283.

9. Martinez-Valdez $\mathrm{H}$, et al. Human germinal center $\mathrm{B}$ cells express the apoptosis-inducing genes Fas, c-myc, P53, and Bax but not the survival gene bcl-2. J Exp Med. 1996;183(3):971-977.

10. Lebecque S, de Bouteiller O, Arpin C, Banchereau J, Liu YJ. Germinal center founder cells display propensity for apoptosis before onset of somatic mutation. JExp Med.1997;185(3):563-571.

11. Nuñez G, Hockenbery D, McDonnell TJ, Sorensen CM, Korsmeyer SJ. Bcl-2 maintains B cell memory. Nature. 1991;353(6339):71-73.

12. Smith KG, Light A, O'Reilly LA, Ang SM, Strasser A, Tarlinton D. bcl-2 transgene expression inhibits apoptosis in the germinal center and reveals differences in the selection of memory B cells and bone marrow antibody-forming cells. J Exp Med. 2000;191(3):475-484.

13. Cong P, Raffeld M, Teruya-Feldstein J, Sorbara L, Pittaluga S, Jaffe ES. In situ localization of follicular lymphoma: description and analysis by laser capture microdissection. Blood. 2002;99(9):3376-3382.

14. Roulland S, Faroudi M, Mamessier E, Sungalee S, Salles G, Nadel B. Early steps of follicular lymphoma pathogenesis. Adv Immunol. 2011;111:1-46.

15. Liu Y, Hernandez AM, Shibata D, Cortopassi GA. BCL2 translocation frequency rises with age in humans. Proc Natl Acad Sci U S A. 1994;91(19):8910-8914.

16. Roulland S, et al. Follicular lymphoma-like B cells in healthy individuals: a novel intermediate step in early lymphomagenesis. J Exp Med. 2006;203(11):2425-2431.

17. Schüler F, et al. Prevalence and frequency of circulating $\mathrm{t}(14 ; 18)$-MBR translocation carrying cells in healthy individuals. Int J Cancer. 2009;124(4):958-963.

18. Hirt C, Dölken G, Janz S, Rabkin CS. Distribution of $\mathrm{t}(14 ; 18)$-positive, putative lymphoma precursor cells among B-cell subsets in healthy individuals. Br J Haematol. 2007;138(3):349-353.

19. Ford AM, Fasching K, Panzer-Grümayer ER, 
Koenig M, Haas OA, Greaves MF. Origins of "late" relapse in childhood acute lymphoblastic leukemia with TEL-AML1 fusion genes. Blood. 2001;98(3):558-564.

20. Ford AM, Bennett CA, Price CM, Bruin MC, Van Wering ER, Greaves M. Fetal origins of the TELAML1 fusion gene in identical twins with leukemia. Proc Natl Acad Sci U S A. 1998;95(8):4584-4588.

21. Wiemels JL, Ford AM, Van Wering ER, Postma A, Greaves M. Protracted and variable latency of acute lymphoblastic leukemia after TEL-AML1 gene fusion in utero. Blood. 1999;94(3):1057-1062.

22. Dogan I, et al. Multiple layers of B cell memory with different effector functions. Nat Immunol 2009;10(12):1292-1299.

23. Pape KA, Taylor JJ, Maul RW, Gearhart PJ, Jenkins MK. Different B cell populations mediate early and late memory during an endogenous immune response. Science. 2011;331(6021):1203-1207.

24. Bende RJ, van Maldegem F, Triesscheijn M, Wormhoudt TA, Guijt R, van Noesel CJ. Germinal centers in human lymph nodes contain reactivated memory B cells. J Exp Med. 2007;204(11):2655-2665.

25. Sungalee $S$, et al. Germinal center reentries of BCL2-overexpressing B cells drive follicular lymphoma progression. JClin Invest. 2014;124(12):5337-5351.

26. Tsai AG, Lu H, Raghavan SC, Muschen M, Hsieh CL, Lieber MR. Human chromosomal translocations at $\mathrm{CpG}$ sites and a theoretical basis for their lineage and stage specificity. Cell. 2008;135(6):1130-1142.

27. Jegalian AG, et al. Follicular lymphoma in situ: clinical implications and comparisons with partial involvement by follicular lymphoma. Blood. 2011;118(11):2976-2984.

28. Muramatsu M, Kinoshita K, Fagarasan S, Yamada $\mathrm{S}$, Shinkai Y, Honjo T. Class switch recombination and hypermutation require activationinduced cytidine deaminase (AID), a potential RNA editing enzyme. Cell. 2000;102(5):553-563.

29. Greeve J, et al. Expression of activation-induced cytidine deaminase in human B-cell non-Hodgkin lymphomas. Blood. 2003;101(9):3574-3580.

30. Smit LA, Bende RJ, Aten J, Guikema JE, Aarts WM, van Noesel CJ. Expression of activationinduced cytidine deaminase is confined to B-cell non-Hodgkin's lymphomas of germinal-center phenotype. Cancer Res. 2003;63(14):3894-3898.

31. Pasqualucci L, et al. AID is required for germinal center-derived lymphomagenesis. Nat Genet. 2008;40(1):108-112.

32. Maruyama M, Lam KP, Rajewsky K. Memory B-cell persistence is independent of persisting immunizing antigen. Nature. 2000;407(6804):636-642.

33. Hope-Simpson RE. The epidemiology of viruses: antigenicity and evolution. Proc $\mathrm{R}$ Soc Med. 1969;62(11 part 1):1138-1142.

34. Pays E, et al. Gene conversion as a mechanism for antigenic variation in trypanosomes. Cell. 1983;34(2):371-381.

35. Brunham RC, Plummer FA, Stephens RS. Bacterial antigenic variation, host immune response, and pathogen-host coevolution. Infect Immun. 1993;61(6):2273-2276

36. Avery SV. Microbial cell individuality and the underlying sources of heterogeneity. Nat Rev Microbiol. 2006;4(8):577-587.

37. Greaves MF. Speculations on the cause of childhood acute lymphoblastic leukemia. Leukemia. 1988;2(2):120-125.

38. Greaves, M. The 'delayed infection' (aka 'hygiene') hypothesis for childhood leukaemia. In: Rook GAW, ed. The Hygiene Hypothesis and Darwinian Medicine. Basel, Switzerland: Birkhäuser Basel; 2009:239-255.

39. Dockerty JD, Draper G, Vincent T, Rowan SD, Bunch KJ. Case-control study of parental age, parity and socioeconomic level in relation to childhood cancers. Int J Epidemiol. 2001;30(6):1428-1437.

40. Anderson LA, Landgren O, Engels EA. Common community acquired infections and subsequent risk of chronic lymphocytic leukaemia. Br J Hae matol. 2009;147(4):444-449.

41. Kristinsson SY, et al. Immune-related and inflammatory conditions and risk of lymphoplasmacytic lymphoma or Waldenstrom macroglobulinemia. J Natl Cancer Inst. 2010;102(8):557-567. 